\title{
ENCONTROS ENTRE TAMBOR DA MATAE TAMBOR DE MINA A PARTIR DO TERECÔ DE CODÓ NO MARANHÃO
}

ENCOUNTERS BETWEEN TAMBOR DA MATA AND TAMBOR DE MINA FROM THE PERSPECTIVE OF THE AFRO-BRAZILIAN RELIGION TERECÔ

\section{Barbara Pimentel da Silva Cruz}

Doutoranda em Antropologia Social pelo Museu Nacional/Universidade Federal do Rio de Janeiro (UFRJ). Fulbright Fellow como Visiting Research Scholar, Department of Anthropology, Graduate Center, City University of New York, 2019-2020. Mestre em Antropologia Social pelo Museu Nacional (UFRJ). Pesquisadora do Núcleo de Antropologia Simétrica do Programa de Pós-graduação em Antropologia Social da UFRJ (NAnSi/PPGAS). Advogada formada pela Faculdade Nacional de Direito da UFRJ. 


\section{RESUMO}

Este artigo pretende pensar etnograficamente os cruzamentos entre diferentes vertentes religiosas a partir da perspectiva do terecô, religião afro-brasileira praticada no município de Codó (MA). Para tanto, parto do sistema de circulação dos praticantes entre as casas de terecô, conhecido como pagar visita, e das viradas entre os ritmos da mina (o tambor de mina praticado em São Luís e em outras cidades brasileiras) e da mata (referente ao terecô no curso dos festejos). Procuro, então, observar em que termos é possível viabilizar um entrelaçamento que não implique um amálgama indistinto nem necessariamente subsuma uma prática religiosa à outra. Desse modo, a incorporação de determinadas forças do tambor de mina pelo terecô se efetiva em termos tais que a relação entre as práticas se estabelece mantendo as diferenças, em uma dinâmica que ilumina a própria noção de encontro.

Palavras-chave: terecô; religião afro-brasileira; sincretismo; Maranhão.

\section{ABSTRACT}

This article seeks to ethnographically reflect on the entanglements between different religious practices through the perspective of terecô, an Afro-Brazilian religion from Codó, state of Maranhão, Brazil. For this purpose, I approach the system of circulation of practitioners between the houses of terecô, and the viradas (rhythm turns) between mina (that refers to tambor de mina, a religion practiced in São Luís and other Brazilian cities) and mata (typical from terecô) in the course of the festivities. Based on these movements, I address in what terms it is possible to enable an entanglement that does not imply an indistinct amalgamation nor necessarily subjugate one religious practice to the other. Therefore, terecô's incorporation of certain forces of the tambor de mina is carried out in such a way that the relationship between the religions is established by maintaining the differences, in a dynamic that sheds light into the notion of encounter.

Keywords: terecô; afro-brazilian religion; syncretism; Maranhão. 


\section{Introdução}

Neste artigo proponho uma análise dos cruzamentos entre práticas religiosas pela perspectiva do terecô, religião praticada no município de Codó, no estado do Maranhão. Não se trata de uma revisão bibliográfica sobre as religiões de matriz africana, tampouco sobre os processos que ficaram conhecidos como sincretismo, para os quais há extensa bibliografia. ${ }^{1}$ Diz respeito a uma abordagem etnográfica sobre a questão das misturas em contextos de religião de matriz africana pelo prisma do terecô. ${ }^{2}$

Pureza e mistura, religião e magia, litoral e interior. Alguns binômios persistiram nas linhas da literatura antropológica sobre religiões de matriz africana ao longo do tempo, ainda que comportando uma série de variações e nuances. Assim, as práticas religiosas encontradas nas capitais litorâneas, em parte consideradas mais estruturadas ou detentoras de estruturas africanas - o tambor de mina maranhense, o nagô e a xambá pernambucanos e sobretudo o candomblé baiano - tenderam a ser foco dos estudos e parâmetros de análise do tema. ${ }^{3}$ No caso do Maranhão, de um modo ou de outro, a literatura antropológica voltou-se majoritariamente para o tambor de mina de tal forma que, nas palavras de Ferretti (200I, p. 20), "falar em religião afro-brasileira do Maranhão até há bem pouco tempo era falar em Casa das Minas". Por outro lado, religiões como o terecô encontram-se em uma região de intensa circulação e cruzamento entre diferentes tradições religiosas, como tambor de mina, candomblé, umbanda, pajelança, espiritismo e catolicismo. Por essa razão, foi de modo geral considerado entre as práticas tidas como altamente sincréticas.

Percebe-se na literatura sobre as religiões afro-brasileiras certo encadeamento de tendência hierarquizante, no qual os discursos sobre o candomblé (sobretudo baiano) terminam se impondo sobre o tambor de mina, que por sua vez se sobrepõe ao terecô, embora em um quadro teórico mais amplo tenham sido todas amiúde percebidas em relação a religiões hegemônicas. Em outras palavras, se a abordagem teórica sobre o candomblé prevaleceu em relação ao tambor de mina, nesse campo de estudos mais restrito, qual seja o

\footnotetext{
${ }^{1}$ Conforme, por exemplo, Serra (1995), Goldman (2009, 2017a), Banaggia (2008, 2014). Especificamente no campo das religiões de matriz africana no âmbito do Maranhão, ver Mundicarmo Ferretti $(1993,2001)$ e Sergio Ferretti (1995).

${ }^{2}$ Todas as citações de diálogos e referências ao material etnográfico são oriundas do meu diário de campo, elaborado ao longo desses nove meses de trabalho de campo. Faço uso dos nomes verdadeiros das pessoas com quem encontrei, seguindo compromissos estabelecidos nesse sentido com meus interlocutores.

${ }^{3}$ Acerca dos distintos momentos nos estudos sobre religiões de matriz africana, em particular sobre as discussões que marcaram a segunda metade do século XX, ver Banaggia $(2008$, 2014). No que concerne aos desdobramentos no campo de estudos mais restrito ao Maranhão, parte do argumento foi desenvolvido em Cruz (2018).
} 
das religiões de matriz africana no Maranhão, esta foi muito frequentemente disposta pela literatura antropológica de modo a sobrepor outras práticas religiosas. Em decorrência disso, o terecô tem sido contado muitas vezes tomando-se por referência elementos e perspectivas de outras religiões de matriz africana, como o candomblé e a umbanda, mas sobretudo o tambor de mina tal qual praticado na capital. Emblemáticas do argumento são as palavras tecidas por Bastide (I97I): por um lado, admirou o tambor de mina (especificamente a Casa das Minas), exaltando-o entre os candomblés tradicionais - estaria assim entre as práticas que fariam de São Luís uma "ilha de resistência africana, mais especificamente daomeana" em meio a uma "zona de influência indígena" -; por outro lado, considerou o entorno, ou o interior, tal qual "uma zona de transição onde o catimbó e o Tambor de Mina abandonam-se às mais estranhas uniões" (p. 266).

Evidentemente, a questão das sobreposições teóricas como aqui disposta não está colocada pelas comunidades ou práticas religiosas em si. Trata-se muito mais dos discursos dominantes, da literatura antropológica mais especificamente, e do modo como, seja pela quase ausência de estudos ou por um olhar desacreditado sobre essas práticas, esse conjunto terminou por reificar um imaginário pautado pelos parâmetros de algumas religiões de modo a ofuscar as dinâmicas intrínsecas a outras. Os pontos de contato, no entanto, não estão ausentes, nem se negam os atravessamentos entre diferentes práticas e contextos. $O$ ponto aqui, portanto, é justamente pensar sobre os encontros entre diferentes vertentes religiosas nas quais a relação não esteja estabelecida de antemão por uma lógica necessariamente hierarquizante. É nesse sentido que a discussão sobre os processos que ficaram conhecidos como sincretismo, em particular onde foram tidos como essas "estranhas uniões", podem ser encarados levando-se em conta que as diferenças não são todas as mesmas e nem se combinam da mesma maneira. Mais ainda, por uma perspectiva na qual o encontro em si apareça mais do que as projeções de resultados únicos dele hipoteticamente resultantes e assim, longe de "estranho", possa ser potente.

Em uma abordagem sobre as misturas que parece diferir do argumento inicialmente apresentado por Bastide (I97I) - ao menos no caso do Maranhão -, Nascimento (2016) propõe um contraste entre o que seriam dois tipos de sincretismo. Se por um lado o catolicismo foi violentamente imposto, de forma que "[o]s negros fizeram uma inversão na fórmula e sacaram dela resultado positivo à preservação e continuidade de sua religião", em uma postura que reflete mais uma "técnica de resistência cultural afro-brasileira do que qualquer das explicações 'científicas' propagadas com fito domesticador"; por outro lado, o fenômeno que efetivamente mereceria o nome de sincretismo seria aquele que "envolveu as culturas africanas entre si, e entre elas e a religião dos índios brasileiros" (NASCIMENTO, 2016, p. I34). Como não poderia deixar de ser, imposições violentas não podem estar no mesmo 
registro de encontros entre fluxos minoritários. Mas há que se considerar o argumento em sua profundidade. É notória a complexidade da relação de todos os elementos que constituem esses universos em contato. Em outras palavras, há a possibilidade de vertentes, correntes, fluxos minoritários internos a todas essas práticas que, em cruzando caminhos justamente nessa chave minoritária, resultarem em mais do que uma postura meramente reativa.

Disso não resulta uma "homologia de diferenças", ${ }^{4}$ como bem explicitou Pinto Filho (20I7) em sua análise das elaborações sobre sincretismo em um terreiro de candomblé nagô do Recife (PE). Mesmo as percepções dos praticantes das incontáveis manifestações de matriz africana e afroindígenas podem variar de acordo com diversas circunstâncias, distanciandose das tantas formas de enquadramentos rígidos, estáticos, engessados. Nesse sentido, Marques (2016) propõe pensar o candomblé como um "modo de habitar o território, concebendo-o como abrigo de distintas forças e fluxos" (p. 60), em uma reelaboração etnográfica do conceito guattariano de território existencial que abre caminho para uma abordagem em que os "tipos" não se sobreponham às "forças". Trata-se, então, de atentar para modos próprios de experienciar e mesmo promover encontros, perceber diferenças, compor cruzamentos, colocar os elementos do mundo em movimento.

De acordo com Nascimento (2016), em trecho em que comenta um texto de Efraím Bó sobre o Teatro Experimental do Negro:

[...] a perspectiva negra de concepção do mundo [...] nada tem a ver com a visão arcaica. Trata-se, para Bó, de uma cosmovisão antiga e atual: "o negro, negro que é, tem olhos e ouvidos e consciência para perceber o mundo e qualificá-lo, reinterpretando-o com seus calejados olhos e ouvidos negros de hoje”. (BÓ apud NASCIMENTO, 2016, p. 162-163).

\footnotetext{
${ }^{4}$ Pinto Filho (2017) analisa as teorias locais sobre sincretismo que perpassam os entrelaçamentos tanto entre candomblé e catolicismo, quanto daquele com a jurema no llê lyemanja Ogunte, terreiro de candomblé nagô do Recife (PE). Para o autor, "candomblé, catolicismo e jurema, mais do que meios de comunicação ou sistemas de classificação, seriam como fenômenos da experiência que guiam e estabelecem modos de interação com o mundo, a partir de certas disposições do universo conceitual que os precipitam" (2017, p. 149). Nesse sentido, as distinções entre o catolicismo e o candomblé, ou entre este e a jurema, não são homólogas entre si, de modo que "não se pode transitar de um universo ritual para outro sem perder de vista as significativas diferenças entre eles" (2017, p. 148-149). Guardadas as devidas singularidades, creio que o raciocínio também se aplica para o terecô. Suas relações com a mina, a umbanda, o candomblé, a pajelança, o catolicismo, não estão todas no mesmo registro ou produzindo os mesmos efeitos. Tanto "o que" de cada uma que se combina difere quanto as formas (o "como") da combinação também variam. Há que se pensar igualmente que não se trata de uma fórmula simplista de adição em que a presença dos elementos produzam um resultado único e preestabelecido. Este trabalho trata da questão do ponto de vista do terecô, e mesmo assim concebendo que há variações entre as tendas, praticantes e singularidades internas à vertente religiosa. Desse modo, do ponto de vista dessas outras práticas, as combinações podem produzir - e efetivamente o fazem - resultados distintos, longe de uma necessária homogeneização laminadora das diferenças.
} 
Por similar prisma, LeRoi Jones (2002) (que posteriormente se rebatizou Amiri Baraka) trata das dinâmicas de adaptação na diáspora em sua análise sobre o jazz, em passagem que vale a citação algo extensa:

E essa me parece uma ideia extremamente importante, já que justamente essa amarga insistência é o que tem resguardado o que pode ser chamado de cultura negra enquanto um brilhante amálgama de múltiplas influências. Houve sempre uma fronteira além da qual o negro não podia ir, seja musicalmente ou socialmente. Houve sempre uma possível limitação para qualquer diluição ou exclusão das referências culturais ou espirituais. $\mathrm{O}$ negro não poderia jamais tornar-se branco e essa era a sua força; em algum momento, sempre, ele encontrava o limite em participar no teor dominante da cultura do homem branco. Foi nessa crucial interseção que ele teve de fazer uso de outros recursos, fossem africanos, subculturais ou herméticos. $\mathrm{E}$ foi essa fronteira, essa terra de ninguém, que proporcionou a lógica e a beleza de sua música. (p. 80, tradução livre).

Diante dos complexos e violentos processos que culminaram nesses "limites", então, "como sempre, as massas de homens negros adaptaram, ao invés de se assimilarem completamente; apropriaram, ao invés de trocarem, um deus ou uma cultura por outra" (JONES, 2002, p. I 24). Por tal perspectiva, o que entra em foco é justamente uma postura ativa - não apenas passiva ou meramente reativa ${ }^{5}$ - nas combinações, nos encontros, nas adaptações. E isso de um modo tal que o que fica não é somente o que se perdeu, o que restou, aquilo que está incompleto ou que foi violentamente enxertado, em uma lógica da falta, recorrente nos discursos dominantes sobre contextos africano-diaspóricos. Pelo contrário, sem ignorar as violências, os riscos e mesmo a história, trata-se mais de uma potência criativa, em movimento, viva. Como sustenta Goldman (2009, p. 134), "essas teorias e práticas partem, ao contrário, do princípio de que lidamos com um mundo pleno, onde o facto de nada faltar não significa que nada haja a fazer - muito pelo contrário".

Nesse sentido, este artigo é um exercício de afastar a sombra das sobreposições que ao longo do tempo, de um modo ou de outro, ofuscaram em parte os estudos sobre o terecô ou tambor da mata, para propor certa torção de perspectiva a partir do procedimento de minoração, conforme elaborado por Goldman (2015), para entrever as "virtualidades bloqueadas pela variável dominante" (p. 646) e vislumbrar o que temos a aprender sobre a

\footnotetext{
${ }^{5}$ Note-se que mesmo naquilo que implica algum tipo de "reação" a uma violência, o sincretismo, no que se refere à combinação com vertentes do catolicismo, também pode ser encarado não como passiva concessão, mas como "procedimento ativo" de "apropriação legítima dos bens do opressor pelo oprimido" (MOTTA, 1982).
} 
arte dos encontros com o universo do terecô. Nada disso implica ausência de ressonâncias e conexões com outras vertentes religiosas de matriz africana, seja no sentido cosmológico seja no sociopolítico. Para acompanhar de que maneira se dão esses movimentos, farei uma breve descrição de um festejo para fins de alguma visualização, embora totalmente insuficiente, do que se passa em um salão de terecô; ${ }^{6}$ em seguida, tratarei de dois temas entrelaçados e ao mesmo tempo centrais: a circulação dos terecozeiros na prática de visitação e as viradas entre tambor de mina e tambor da mata no curso dos festejos.

O terecô é religião de matriz africana, também chamado frequentemente tambor da mata ou mata pelos brincantes, e identificado na literatura antropológica como Brinquedo de Santa Bárbara, Verequete ou Encantaria de Barba Soeira. Concebe a incorporação sobretudo de encantados da mata, que se organizam em famílias. ${ }^{7}$ Segundo o pai de santo Pedro d'Oxum e a encantada Chica Baiana, são três as famílias de encantados em Codó: de Légua Boji, que é de fora, mas adotou Codó como sua terra; de Angassu e de Babassuê, ambas das matas da região. "Santa Bárbara e Légua Boji Buá da Trindade são as firmezas e os patronos da encantoria", assim me explicou a mãe de santo Teresinha. A primeira é tida como a chefe da encantoria, muitas vezes associada a Iansã, e o segundo é chefe da família mais numerosa, conhecida e atuante no terecô, que em geral se apresenta afirmando ter uma banda branca e uma preta, metade de Deus e metade do Diabo.

Entidades tais como caboclos, pretos velhos e princesas, ainda que possam remeter àquelas pertencentes a outras vertentes religiosas, estão igualmente abarcadas pelo termo encantado ou vodunso. Na visão de brincantes e mães e pais de santo com quem me encontrei,

\footnotetext{
${ }^{6}$ Para descrições etnográficas mais extensas ver Ahlert (2013), Cruz (2018), Ferretti (2001), Lamy (2016) e Lima (2017, 2019).

${ }^{7}$ A organização em famílias está registrada na literatura antropológica (AHLERT, 2013; FERRETTI, 1993, 2001; FERRETTI, 1985; LIMA, 2017; PRANDI, SOUZA, 2011). M. Ferretti (1993) afirma que no tambor de mina há uma classificação de acordo com diversos critérios, tais como categoria, família, linha ou nação. Nesse sentido, as entidades "são organizadas em famílias extensas, tanto por pais-desanto quanto pelos membros menos graduados dos terreiros. As famílias de voduns da Casa das Minas e de 'bonsus' da Casa FantiAshanti são constituídas por parentes consanguíneos e não consanguíneos [...]. Esta forma de organização é também encontrada entre os gentis (fidalgos) e caboclos, tanto em São Luís como em Belém do Pará [...]" (p. 100). Importante notar, no entanto, que essa explicação parte da visão dos praticantes do tambor de mina interlocutores da autora. Sobre a questão, Ahlert (2013) afirma que "[m]uitas dessas classificações são também referidas em Codó, onde os encantados podem ser relacionados à linha da Mata, mas também ser entendidos como caboclos (enquanto categoria), como uma família extensa (a família de Légua, por exemplo), como o povo de Codó (quando relacionados à região de origem, diferente, portanto, do povo da Bahia, do Pará, do Ceará etc.)" (p. 21, grifo nosso). Para uma enumeração das famílias de encantados e indicação das características de alguns de maior destaque, ver Prandi e Souza (2011). Embora a lista (notavelmente extensa) tome por base a Casa das Minas de Tóia Jarina, em São Paulo, fornece um bom panorama da extensão e das características dos encantados relativos também ao terecô. Ver também Lima (2017), sobre a família de Légua, e Ahlert e Lima (2019), sobre as tramas de parentesco entre pessoas e encantados no terecô de Codó.
} 
todas as entidades que descem ${ }^{8}$ pertencem à mata, são das matas, das pedras, dos rios, das encantorias. Assim, ainda que uma entidade "estrangeira" passe a integrar o corpo infindável de entidades que tomam parte nos rituais da mata, o fato de "vir de fora" não implica que não "pertença" à mata e, por outro lado, esse processo também não impede que a entidade continue aparecendo em outras partes. A história de Légua Boji Buá talvez seja ilustrativa do ponto. A entidade, conforme mencionei algumas linhas antes, veio "de fora" e adotou Codó como sua terra; é, portanto, um "de fora" que é também "de dentro". Note-se ainda que Légua Boji é conhecido por continuamente adotar novos membros que são acolhidos no corpo da família - e eles, de certa forma, também adotam Codó e o terecô.

A organização se dá em tendas comandadas por pais e mães de santo. Entretanto as relações extrapolam os limites de cada casa, e há uma intensa circulação, de modo que é comum ouvir que para conhecer o terecô é preciso conversar com diversos brincantes. A comunidade é formada por um emaranhado de relações, com o compartilhamento de laços de parentesco, entidades, obrigações, relações de apadrinhamento, cruzamentos vários entre as casas. Há, por exemplo, quem celebre aniversário de encantado em algum terreiro amigo, ou um pai de santo cujo filho carnal - ou seja, de sangue - seja filho de santo de outra casa, mas ainda assim participe ativamente das atividades de sua casa.

Na narrativa local, o terecô nasceu na comunidade quilombola de Santo Antônio dos Pretos, a cerca de $80 \mathrm{~km}$ do centro de Codó, pelos idos do século XVIII. O ritmo da mata é predominante nos toques, que chegam a durar várias noites seguidas, e frequentemente inclui também os ritmos mina corrida e mina dobrada, as denominadas viradas entre mina e mata. Cada terreiro de Codó oferece ao menos um grande festejo no ano, homenageando um santo, um orixá, um encantado ou mesmo um grupo de entidades, ocasião na qual recebe integrantes de outras casas no salão preparado especialmente para a data. A circulação do povo de terreiro entre as diferentes casas através dos festejos é uma característica incontornável, e é marcante a prática de pagar visita ou pagar noite, já registrada na literatura sobre a região (AHLERT, 20I3; CRUZ, 20I8; LIMA, 20I7, 20I9), na qual os integrantes de uma casa visitam os festejos das demais casas na expectativa de que haja o movimento recíproco. Tal prática envolve brincantes de tendas de terecô, mas também de outras religiões afrobrasileiras, além de convidados de outras cidades maranhenses e inclusive outros estados, particularmente Piauí e Pará. Embora haja uma variação das práticas constitutivas das tendas relativa à lógica de organização das forças que a compõe e depende de pessoas,

\footnotetext{
${ }^{8}$ Subir, descer e baixar são termos relativos aos processos de incorporação e desincorporação.
} 
entidades, rituais, obrigações e um sem número de variáveis, os festejos costumam ter uma dinâmica recorrente que os caracteriza, descrita em linhas gerais a seguir.

\section{Baiar terecô}

Os foguetes estouram no céu anunciando o início do toque, como é comum nos dias de festa nos terreiros da cidade. Aos poucos, integrantes de outras casas adentram o portão que dá para o terreno contíguo à casa de moradia, arrumado com mesas e cadeiras e com um bar que vende bebidas e controla o aparelho de som que toca as músicas do momento, principalmente os bregas e arrochas. Logo na entrada da porta da rua vê-se um cruzeiro grande, todo azulejado. No fundo há um salão coberto, com um portão próprio e amplas janelas ocupadas por aqueles interessados em observar. As pessoas de uma mesma casa costumam chegar juntas, em roupas de cores coordenadas. Cada grupo faz, de modo mais ou menos discreto, algum tipo de pequeno ritual: alguns fazem o sinal da cruz, outros encostam no grande cruzeiro ou fazem um gesto no canto do salão.

A mãe ou o pai de santo da casa adentra o barracão segurando uma cabaça, seguida em fila por suas filhas e seus filhos de santo, formando um círculo. O couro dos tambores já está aquecido e os tamboreiros a postos esperam o momento de iniciar o toque. Uma vela acesa bem no centro do salão reflete a chama no piso de azulejo. Formando um círculo ao redor do lume, os filhos de santo ajoelham e inclinam o corpo até chegar próximo ao chão. Inicia-se, então, o louvariê, obrigação que abre os festejos principais das tendas de terecô. É o momento em que são evocados o vodum Verequete, ${ }^{9}$ as entidades da mata e aquelas ligadas à casa. Todos cantam fazendo o chamado, respondendo em coro "louvariê!" a cada chamada, ao mesmo tempo que batem com as duas mãos no chão em um ritmo coordenado com os tambores e as cabaças. Em seguida, o líder ergue-se, movimento seguido pelos demais, enquanto o ritmo da louvação ganha uma marcação mais definida e progressivamente acelerada. Lentamente há uma transição para a mina e para as doutrinas ${ }^{10}$ cantadas nesse toque. O grupo começa a girar devagar, em passos curtos para frente e para trás, voltados para o centro do salão, no sentido anti-horário. O ritmo acelera progressivamente. Ouvidos

\footnotetext{
${ }^{9}$ Como me contou a mãe de santo Teresinha, e é comum ouvir em Codó, o louvariê e as evocações ao vodum Verequete servem para "puxar o povo da mata" e "organizar as correntes". Embora seja recorrente ouvir que de maneira geral o vodum não costuma descer ou incorporar (o que não significa necessariamente que nunca o faça ou que isso seja impossível) em Codó, me parece que sua presença também é fundamental na organização das correntes espirituais e na dinâmica dos encontros entre diferentes forças que acontece no tambor da mata, como arrisquei desenvolver em Cruz (2018).

${ }^{10}$ Doutrinas são os pontos cantados para as entidades, músicas que homenageiam, relembram fundamentos, puxam correntes de entidades.
} 
leigos têm certa dificuldade em discernir o momento exato em que se dá a virada; o cantador passa a puxar as doutrinas da mata e logo se vê que a formação da roda muda sutilmente, disposta em fila e em um passo combinado com pequenos giros.

Os convidados não param de chegar, e em certo momento a impressão é de que o barracão não é capaz de dar conta da quantidade de gente que adentra. Aos poucos, no entanto, todos se acomodam, formando outra roda mais encorpada em uma mescla cada vez mais profusa de cores. A temperatura do salão aumenta, intensificando a sensação de que o ritmo está acelerado. Algumas entidades se demoram em frente à bateria, composta por tambores com uma extremidade coberta com couro animal ${ }^{11} \mathrm{e}$ maracás, além de outros instrumentos, como o tarol. Os tamboreiros fazem viradas nos instrumentos seguindo os movimentos corporais, em um diálogo sutil. A dança se faz mais enérgica, os gestos mais amplos, os giros mais vigorosos. De repente, os tambores param e as pessoas também. Aquelas que estão no meio do processo de incorporação levam a mão ao rosto, em uma expressão de algum tipo de aflição. As entidades que dançavam efusivas, diminuem um pouco a intensidade e aguardam os próximos momentos. Alguns saem do salão em direção à área externa, à procura de alguém que pague uma escumosa, isto é, uma cerveja. Do lado de fora, encantados circulam entre os convidados brincando, bebendo e fumando, rodando suas saias, conversando e cumprimentando uns aos outros e às pessoas que encontram. Alguns minutos se passam até que um dos tocadores adentra o barracão carregando um "novo" tambor, recém-aquecido, enquanto outro leva para fora aquele que estava sendo tocado até então, que agora precisa ter o couro novamente dilatado e tensionado no calor da fogueira acesa nos fundos do terreno.

O toque recomeça, outro cantador inicia as doutrinas na mina, acompanhado pela bateria. Em pouco tempo ocorre a transição para a mata. $O$ ritmo, a dança, a temperatura, tudo esquenta novamente. Mas é perceptível que uma parte significativa dos encantados ficou do lado de fora, mais interessados nas escumosas do que no baiado. Os tambores pausam para que, no microfone, o líder da casa convoque todos a entrar. Alguns obedecem, outros parecem não acusar o puxão de orelha. Recomeça o som direto na mata.

Alguém anuncia a presença de amigos de outro terreiro e pede uma salva de palmas, chamando um representante daquela casa para puxar o canto. Recomeça o toque, na mina, seguindo a doutrina puxada por aquele novo cantador. Pouco tempo depois, viram para a

\footnotetext{
${ }^{11}$ Segundo o abatazeiro Piauí, os tambores são preferencialmente cobertos com couro de veado, embora seja cada vez mais raro ter a oportunidade de utilizar a pele desse animal. Os abatazeiros normalmente cuidam da manutenção dos tambores passando gema de ovo para hidratar o couro e evitar os efeitos inevitáveis de desgaste pelo tempo. Antes de tocar, é preciso aquecê-lo próximo a uma fogueira para que dilate, permitindo assim que reaja ao toque produzindo o som desejado, em um processo de afinação do instrumento.
} 
mata e o ritmo, a temperatura, os passos e o toque progressivamente se intensificam outra vez. De repente, tudo arrefece e o toque volta para a mina, iniciando o mesmo ciclo mais uma e outra vez, como acontecerá ao longo de todo o dia ou toda a noite, até que se encerre aquela obrigação.

\section{Pagar visitas, ganhar visitas}

Diante da pergunta acerca da data do festejo de uma casa, a resposta dos terecozeiros em geral diz respeito àquele ou àqueles que são considerados os "principais" daquela tenda. No entanto a convivência com o povo de terreiro em Codó por algum tempo logo revela que são muitos os toques e seus motivos. Não por acaso, é quase certo que haja alguma cerimônia em qualquer noite do ano. ${ }^{12} \mathrm{~A}$ única exceção é o período entre o carnaval e a semana santa. Não há toques durante a quaresma e deve-se observar algumas restrições, como não comer carne, abster-se de relações sexuais, manter os santos cobertos por um tecido e realizar atendimentos apenas em casos de emergência e forte necessidade.

Além do festejo principal, podem haver toques para reabrir a casa após a quaresma, obrigações específicas, aniversários de encantados, entre outras tantas possibilidades. Segundo Ahlert (20I3), a "casa/tenda vive intensamente o festejo - e vive por dentro, sendo ocupada pelos encantados e pelos visitantes". Por outro lado, "o festejo também lança o terecô para a rua e para a cidade, pois a partir dele os encantados saem das casas e acompanham procissões, assistem a forrós e serestas, se deslocam para visitar tendas e levar seus 'cavalos de volta para casa"' (p. I53), de forma que espaços e tempos não são necessariamente pensados em termos de domínios religiosos e rituais distintos. O segundo semestre é o mais intenso, pois grande parte das tendas concentra seus festejos principais nessa época. $\mathrm{O}$ calendário dos brincantes fica cheio de compromissos por conta da prática de ganhar ou pagar visitas, na qual uma casa vai ao festejo de outra para que quando for sua vez tenha também muitos convidados, na constituição de uma rede de reciprocidade. Pode-se dizer que a visita, assim como no caso das jornadas observadas por Goltara (2016) nas irmandades religiosas no sul do Espírito Santo, "nunca é um evento que se encerra em si mesmo, mas é sempre o desenvolvimento de visitas anteriores e a criação de outras que estão por vir" (p. 36).

O movimento de visitas não se restringe às casas de terecô - os praticantes de candomblé, por exemplo, também visitam e são visitados em Codó - e tampouco à cidade, uma vez que os terecozeiros circulam entre outras cidades maranhenses, a capital com seus

\footnotetext{
12 "É difícil estimar a quantidade de festejos realizados em Codó. Se temos em média duzentas e cinquenta tendas na cidade e se cada uma delas tiver apenas um festejo de três dias por ano, teríamos cerca de duas tendas tocando tambor por dia. Esse dado é uma suposição, apenas para ilustrar a frequência das festas” (AHLERT, 2013, p. 141, nota 138).
} 
terreiros de mina, e mesmo em outros estados, sobretudo Pará e Piauí. É, portanto, fator que promove e amplia o espectro de possibilidades de encontros. Consequentemente, receber pessoas de outras cidades e mesmo de outros estados é parte do cotidiano dos terreiros de Codó: filhos de santo que moram longe, brincantes que chegam para pagar ou ganhar noites, pesquisadores e curiosos. Os visitantes de longe normalmente chegam cedo por conta do transporte escasso e da distância e, portanto, esperam por longos períodos. Por esse motivo, estão sempre disponíveis pequenos quartos, a maioria do lado de fora da casa principal, no pátio, em construções frequentemente feitas de pau a pique, preparadas para receber as redes dos visitantes que podem descansar até o início dos trabalhos e mesmo ao longo da noite ou nos intervalos para descanso e alimentação dos médiuns.

Receber bem é uma grande preocupação para pais e mães de santo, que se mobilizam ao longo do ano para guardar recursos e fazer parcerias que viabilizem a realização de um bom festejo, com muitos visitantes bem recebidos. É responsabilidade do anfitrião providenciar espaço para guardar pertences e dormir (normalmente em redes, que podem ser trazidas pelos convidados; mas deve haver espaço com prendedores adequados), bem como a alimentação, pelos dias em que durar a celebração. Em Codó não há transporte público e a maioria das pessoas circula a pé, eventualmente utilizando motos e bicicletas. Em dias de festejo é comum ver grupos de integrantes de uma tenda caminhando em direção à casa anfitriã daquela noite, já nos trajes dos encantados (geralmente em cores coordenadas entre os membros de uma mesma tenda), formando bonitos cortejos coloridos pelas ruas da cidade.

Nos dias que se seguem a um festejo ou a uma visita, não é de se espantar que as pessoas comentem os acontecimentos das noites passadas e façam uma espécie de "balanço" dos encontros e das situações que se apresentaram. Nesse contexto, as visitas ocupam alguma centralidade, com muitos comentários girando em torno de quem foi ou deixou de ir, se ficou até de manhã ou se foi embora "ainda no escuro", se atendeu a apenas um, a alguns ou a todos os dias, seguindo-se comparações com o esforço que a casa que recebeu fez nos festejos anteriores da casa visitante. Há, portanto, uma observação atenta às dinâmicas de pagar visita que determina em que festejos - e consequentemente em que relações - será investida a energia dos brincantes, que prestigiam com mais ou menos gosto e empenho os toques de outras casas a depender da reciprocidade de seus visitantes. Se a mãe ou o pai de santo não comparece pessoalmente, pode determinar que alguns de seus filhos compareçam em nome da tenda. A quantidade de pessoas enviada também é foco de análise dos demais terecozeiros, tendo em vista que as visitas, entre outros tantos motivos, se prestam a embelezar e fortalecer os festejos uns dos outros; a beleza, portanto, é também medida pela casa cheia. 
Pais e mães de santo, filhos de santo, brincantes, abatazeiros, ${ }^{13}$ todos devem observar suas obrigações e atentar para os cuidados a serem tomados a fim de manter o corpo preparado para os rituais de que tomam parte. Na visão do tamboreiro Piauí, hoje em dia pais e mães de santo perderam muita força em comparação a como era antigamente, justamente porque muitas dessas regras foram flexibilizadas. Às vezes a negligência de um brincante ou de um tamboreiro em relação a tais cuidados pode afetar o andamento do toque como um todo, abrindo espaço para divergências, obstáculos inesperados e problemas no andamento dos toques ou entre as pessoas de uma maneira geral.

A circulação entre os terreiros não é exclusividade do universo do terecô, embora este pareça mostrar de forma privilegiada a questão. Nas irmandades de santo presentes nas comunidades negras do Vale do Itapemirim (ES), Goltara (2016) afirma a presença de "uma multidão de espíritos que interagem com as irmãs e os irmãos, manifestando-se de diversas formas", conformando um "emaranhado das alianças que conectam vivos e espíritos" (p. 3435). As jornadas, então, aparecem como movimentos múltiplos que englobam desde a dinâmica de visitas rituais recíprocas (particularmente ressonante com o terecô) até as correntes espirituais e os trânsitos das entidades entre planos materiais e espirituais de existência (GOLTARA, 20I6). Em outro caso, Barbosa Neto (2012) comenta o movimento entre as casas no batuque do Rio Grande do Sul, no qual cada casa "dispõe de ampla autonomia para realizar os seus rituais, mas, por outro lado, há, ou pode haver, uma intensa circulação entre elas" (p. 98). As casas se visitam e promovem um intercâmbio, em geral centrado nos níveis mais públicos da vida cerimonial. Assim como no terecô, a parte menos visível só é acessada por aqueles que têm relação mais próxima, em geral marcada por algum laço de parentesco religioso. Nesse sentido, pode ser que as festas públicas, dentre outras funções, promovam uma abertura que viabiliza uma série de trocas em variados níveis. É o que se depreende da citação de Barbosa Neto (2012) a Edson Carneiro que "dizia que 'os homens do candomblé quase nunca se contentam com ver apenas as festas de sua casa' e atribuía a esse ‘hábito andejo' o sincretismo interno às ‘seitas africanas”” (p. 99).

As próprias entidades, não raro, carregam histórias de andanças pelo mundo. Algumas relatam terem vindo da África e passado por outros estados brasileiros antes de adotarem a mata de Codó. Pode ser mesmo que, em sentido análogo ao que se passa na jurema, no Recife

\footnotetext{
${ }^{13}$ Utilizo, seguindo as referências dos terecozeiros de Codó, abatazeiro, tamboreiro, tamborzeiro e, de maneira menos frequente, cabaceiro ou maracazeiro como sinônimos. Além dos termos serem mobilizados para se referir aos músicos de maneira genérica, estes revezam as funções ao longo do toque. É mesmo difícil mensurar exatamente quantos estão envolvidos na bateria de um toque, tendo em vista que há aqueles que chegam vestidos com roupas da tenda ou ao menos coordenadas com as roupas dos demais brincantes, porém é comum que pessoas que sabem tocar - não necessariamente ligadas à casa em questão e mesmo pessoas não preparadas - se aproximem e tomem parte nos instrumentos também. Sobre o ponto, ver Lamy (2016).
} 
(AMORAS, 2020), as entidades visitem diferentes planos, algo como espaços de encantaria. ${ }^{14}$ Há outros tantos relatos de "trânsitos" entre diversas croas, ${ }^{15}$ seja em momentos distintos no tempo, ${ }^{16}$ seja porque os encantados, diferentemente do que a literatura registrou de modo geral sobre os processos de feitura de orixás, podem circular em vários cavalos. Como me explicou o brincante Raí, em ocasião em que visitava a tenda Nossa Senhora da Conceição, comandada pela mãe de santo Teresinha, "o encantado é um só, mas aparece em várias croas". No caso, fazia referência a uma entidade que passava tanto na croa de um brincante de terecô de uma casa de Codó quanto na de um brincante de uma casa de tambor de mina paraense. Dona Teresinha afirma, no mesmo sentido, que "um guia não é feito só para uma cabeça, é para várias cabeças". Ele tem a possibilidade, se quiser, de irradiar outras pessoas enquanto incorporado em um médium, afetando seu comportamento. Alguns médiuns, na medida em que se conectam através das entidades, se aproximam, passam a se visitar e mesmo a se enxergar como amigos ou família. Nesses movimentos, transmitem e adquirem novos conhecimentos e experiências, conectam pessoas, estabelecem vínculos e promovem encontros.

Junto aos médiuns, portanto, caminham seus guias e encantados, de modo que há sempre a possibilidade de conhecer uma nova entidade, que carrega consigo todo um novo corpo de conhecimentos - doutrinas, histórias, práticas ritualísticas, saberes vários, tramas de parentesco. Em tal processo de circulação, portanto, há sempre a possibilidade de aprender algo ou, utilizando a afirmação de Goldman (2012), de capturar energias a partir dos diversos agenciamentos que emergem desses encontros: "os centros de culto das religiões de matriz africana no Brasil poderiam perfeitamente ser compreendidos como enormes máquinas destinadas à captação, à distribuição e à circulação da força única que, em suas cosmologias, constitui tudo o que existe e pode existir no universo" (p. 279).

Assim, nos encontros - entre tendas, ritmos, líderes espirituais, médiuns, encantados, entidades, vertentes religiosas - está a possibilidade constante de dar passagem a algum novo

\footnotetext{
${ }^{14}$ No caso da jurema de Recife, Amoras (2020) afirma que as cidades são "um denominador comum entre os diferentes vocabulários rituais" (p. 14 ), lugares de onde os mestres e outras entidades vêm para trabalhar. Os juremeiros também experimentam viagens pelas cidades da jurema, como acontece, por exemplo, através dos sonhos. A autora nota ainda que é "difícil definir o quanto essas cidades tem de dimensão intangível e tangível” (p. 14, nota 10 ). No caso do terecô, é frequente ouvir que as entidades são das matas, das pedras, dos rios, das encantorias, em uma referência a outras dimensões espaciais que tanto constituem quanto são atravessadas pelos encantados, de modo que essa compreensão sobre o que é tangível ou intangível também é complexa nesse contexto.

${ }^{15}$ Croa é "coroa" ou "cabeça", e a expressão diz respeito ao conjunto de entidades que acompanham e formam a corrente de um médium.

${ }^{16}$ Como um forte exemplo, a encantada Chica Baiana conta que está na família de Seu Pedro há anos; esteve com sua tataravó, bisavó, o avô, ocasião em que fez, ela mesma, o parto do pai de santo. Chegou no Brasil pela Bahia, veio para o Maranhão e desceu para o Codó, onde foi adotada pela família de Seu Légua Boji Buá da Trindade. São muitas as histórias de encantados que foram adotados pelas famílias já estabelecidas, particularmente a de Légua Boji, que parece estar se ampliando constantemente.
} 
conhecimento ou à incorporação de alguma técnica ou energia capaz de potencializar as práticas de uma tenda, em um exercício de propagação de axé (BARBOSA NETO, 2OI2). Obviamente, há que se levar em conta que toda essa dinâmica implica riscos que estão de certa forma previstos - no sentido de ter ciência da sua existência - e que devem ser manejados. "Circular é, desta forma, também colocar-se em uma posição de vulnerabilidade. Decorre dessa constatação a percepção de que é preciso reconhecer a presença de 'forças' e energias, boas e ruins, operando nos diferentes espaços", escreveu Ahlert (2013, p. 243). No mesmo sentido, Barbosa Neto (2012) sustenta que "[e]sse é um perigo que sempre se corre: propagar o axé é importante, mas é também arriscado, pois, ao fazê-lo, está-se igualmente tornando-o disponível para um uso contrário" (p. IOI, grifo nosso). Conecta-se aqui, portanto, aquilo que expressaram a mãe de santo Teresinha, o pai de santo Pedro d'Oxum e o abatazeiro Piauí acerca das necessidades de cuidado e proteção antes de um festejo ou ritual: diante da imprevisibilidade e do caráter aberto dos encontros é preciso se cuidar. Se em um lugar que tem muita gente "tem bom e tem ruim", é preciso fazer suas obrigações e se proteger para conservar o corpo limpo e não dispersar a energia, de modo a poder chegar "de peito aberto" e "coração limpo" - logicamente já protegido - para se abrir a esses encontros e contribuir com os festejos das demais tendas.

Os festejos emergem, portanto, como espaços fundamentais de atualização dessa dinâmica na qual sempre há estrangeiros, hóspedes e visitantes que são recebidos nessa chave: é preciso observar uma série de cuidados e preparações de toda ordem para entrar na casa de quem recebe e para receber aqueles que vêm de fora e sempre carregam consigo algo de novo ou imprevisível, uma doutrina ou um encantado novo, mas sobretudo uma atualização das possibilidades do encontro e da incorporação e potencialização de forças. Assim, "mais do que uma 'instituição', uma 'forma' ou uma 'identidade', o terreiro pode ser pensado como uma espécie de complexo irradiador e receptor de diversas forças" (MARQUES, 20I6, p. 6I). Os festejos abrem espaço para que "as conexões produzidas particulariz[e]m as forças abstratas que circundam as entidades espirituais" (GOLTARA, 20I4, p. 22, grifo nosso). E é nessa chave que se dão os entrelaçamentos entre o terecô e o tambor de mina ora em destaque. Se os cruzamentos entre diferentes práticas não é tema exclusivo desse contexto, é certo que o modo como as coisas entram em contato varia. As viradas entre a mina e a mata dentro dos toques de terecô podem iluminar a questão.

\section{Virar para a mina, virar para a mata}

São muitas as ocorrências da noção de virar no contexto das religiões de matriz africana, em múltiplas possíveis acepções. Virar no santo, virar de nação, virar de lado, virar 
instrumentos, virar ritualmente. As viradas, portanto, são tema recorrente nesse campo de estudos e podem fazer referência a fenômenos distintos - da incorporação às variações musicais, incluindo aí mudanças rituais e passagens entre vertentes religiosas. Goldman $(2017 \mathrm{~b})$ se refere à notável polissemia do verbo "virar" no português brasileiro para pensar as singulares mobilizações da noção em contextos negros, indígenas e afroindígenas. Em seu argumento, que creio valioso para a presente discussão, o que sobressai é "virar enquanto verbo, não naquilo que supostamente seria seu telos", na medida em que "parece estar sempre sendo conjugado no gerúndio - um virando mais do que um virar" (p. 30), referido mais a um movimento do que à efetivação de uma identidade estática. No caso do terecô, as viradas estão mergulhadas nessa mesma chave das "combinações criativas de forças", mas têm uma acepção específica, e é nesse ponto que proponho que nos detenhamos agora.

É comum que ao longo de um toque de terecô ocorram viradas para a mina e viradas para a mata, ou seja, que em determinados momentos do ritual o ritmo seja alterado, juntamente com as doutrinas cantadas e os passos de dança, que se mantém em roda. Tais viradas variam de tenda para tenda e mesmo de toque para toque dentro de uma mesma casa, a depender das entidades homenageadas ou invocadas, do tipo de ritual ou obrigação, dos visitantes presentes, entre tantas outras variáveis possíveis. Conforme ouvi diversas vezes dos brincantes e está registrado na literatura (FERRETTI, 200I; AHLERT, 20I3), a explicação mais comum é que tocar mina em determinados momentos rituais serve para descansar os médiuns, tendo em vista que o toque da mata é intenso e de andamento rápido: em outras palavras, nada muda, como ouvi algumas vezes em Codó. Sem recusar tais explicações, voltemos alguns passos. Dentro dos salões de terecô encontramos três ritmos básicos: mata, mina corrida e mina dobrada. A mata prevalece ao longo da noite, sendo o ritmo que caracteriza o terecô, também chamado de tambor da mata. A mina dobrada é um ritmo mais lento e cadenciado, normalmente executado no início de algumas obrigações; vez ou outra é tocada quando muda o cantador, por exemplo, no que se denomina virar para a mina. A mina corrida, que também pode se enquadrar como uma virada, guarda uma diferença muito sutil com a mata, de modo que os ouvidos leigos muitas vezes têm dificuldades em diferenciá-las.

Seja como for, as viradas dependem de uma série de fatores manejados por pais e mães de santo, encantados, bateria e cantadores (que podem ser os convidados), e não corresponde a momentos rituais distintamente marcados, como vemos em outras manifestações de matriz africana. Nesse sentido, não se trata da virada que encontramos com mais frequência na literatura sobre o tema, na qual há uma mudança de nação ou vertente religiosa; é bem verdade, no entanto, que eventualmente há entidades que não permanecem quando a mudança de toque se efetua. Por exemplo, a mãe de santo Iracema explica que as princesas sobem quando vira para a mata e que nem todas as entidades "aguentam o rojão de baiar a 
noite toda" porque a "mata é muito forte". Tal momento, que talvez marque uma diferenciação maior, normalmente se concentra no início do toque, constituindo a obrigação daquele dia. Muitos brincantes afirmam que o ritmo no qual se iniciam obrigações e toques é a mina. Ressalte-se novamente, no entanto, que nada disso implica alguma regra, dadas as variações internas às casas de terecô. Em boa parte dos toques não se percebe uma diferenciação tão marcada entre os momentos, mais presentes em dias nos quais há, por exemplo, aniversário de um encantado ou arriada de princesas. Seja como for, logo vira para a mata, ritmo tido como do terecô e mais apreciado pelos terecozeiros. As viradas ao longo da noite, então, podem se dar sem intervalos ou ser marcadas por uma breve pausa na qual os tambores são levados para ter o couro aquecido na fogueira acesa na parte externa do salão.

É preciso destacar que médiuns e encantados - ou seja, quer incorporem ou fiquem puros - não dançam ininterruptamente a noite inteira. Há sempre gente baiando no salão enquanto uma parte dos encantados circula do lado de fora, bebendo, dançando e conversando entre si e com os visitantes. Nesse sentido, a questão ganha certa torção e nos faz pensar nas razões da mudança no toque para evitar o cansaço se há a possibilidade de sentar, relaxar e mesmo dormir - quando o médium está puro e há redes disponíveis nos pequenos quartos utilizados pelas visitas. Não se trata em hipótese nenhuma de colocar em dúvida a explicação dos brincantes; proponho levar a questão adiante e pensar os desdobramentos que o discurso acerca das viradas, e a própria prática em si, comportam e o que podem nos ensinar acerca da dinâmica do terecô e de seus encontros com outras vertentes religiosas. Diante disso, um caminho talvez seja pensar se o cansaço a ser evitado é o cansaço físico, como tendemos a pensar. Creio que não, ou pelo menos que não se refira "apenas" a isso.

"O tambor bate com força", é uma expressão recorrente entre os terecozeiros para se referir a um bom toque, em uma definição que passa pela casa cheia e por muita energia. A presença dos visitantes, das entidades, o desempenho dos tamboreiros e tudo que constitui o festejo determina se o toque será percebido como "fraco" ou "forte". A música e o desempenho dos tocadores certamente exercem um papel central. A bateria é composta particularmente por tambores e maracás, mas também pode contar com o tarol e outros instrumentos. Costa Eduardo (1948) registrou, por exemplo, a presença de berimbaus, e Seu Claudionor, falecido marido da mãe de santo Teresinha, era conhecido por tocar lindamente o sax, compondo de maneira singular o conjunto de músicos em toques pela cidade. Os tamboreiros podem fazer parte de uma casa, mas em geral não são os únicos levando um toque: as casas visitantes podem levar os próprios músicos ou mais tamboreiros podem ser chamados para engrossar o corpo de tocadores em um festejo. Enquanto há a possibilidade de pessoas não preparadas tocarem, a preocupação sobre o desempenho da bateria é crucial, incluindo a relação com os 
cantadores e também com aqueles que estão baiando no salão - um diálogo, portanto, entre bateria, cantadores, doutrinas puxadas e passos de dança. Lamy (2016) propôs a questão em termos de uma relação entre música ${ }^{17}$ e força, de modo que se os instrumentos forem mal tocados "podem diminuir a 'força' da 'gira' ou até fazer subir encantados" (p.4I), de modo que a "boa performance sequencial de uma festa de Terecô é saber alternar os momentos de grande, média e baixa intensidade para manter o comprometimento de todos até o fim da festa" (p. 73).

Nesse sentido, a música é uma dimensão de uma espécie de manejo das forças, chamando ou afastando alguma entidade, aumentando e diminuindo a intensidade de acordo com os momentos do toque e mantendo sua firmeza. A virada para a mina, destarte, aparece como um elemento fundamental, e a operação ganha outra dimensão. As afirmações de Barbosa Neto (2012) para a ocorrência da ideia de cruzar que aparece nas casas religiosas de matriz africana do Rio Grande do Sul podem somar a essa reflexão. Segundo o autor,

Cruzar, nesse caso, não é tornar idênticos, mas sim fazer propagar uma forma ritual, a saber, usar a ação que se encontra aí implicada para transformar uma outra ação. Uma forma não se propaga sem a redistribuição da força que a constitui. Usa-se, portanto, o lado do batuque ou da nação, mais precisamente o modo de culto aos orixás que ele contém, para transformar o lado da umbanda e a sua maneira de ritualizar os exus. A proximidade entre os lados é criada por dentro da própria separação existente entre eles. (p. 36).

À luz dessas ideias talvez possamos compreender o virar para a mina como um exercício de modulação de forças, com o toque operando como um dos mecanismos de manuseio de energias que, de outro modo, poderiam "sair do controle", provocando efeitos indesejados sobre os médiuns e sobre o ritual em si. Utilizam-se, para tanto, procedimentos para chamar, afastar, impulsionar, manter ou arrefecer a força ou a energia. Em sentido análogo, o tamboreiro Piauí me explicou que quando o encantado chega, ele vem pesado, pois "nem o corpo do médium está preparado, nem o encantado está confirmado". Dessa maneira, são necessários certos procedimentos para tirar um pouco da força da entidade (bater nas articulações, por exemplo), viabilizando a incorporação, em mais uma das técnicas empregadas no manejo dessas forças. Essa modulação não atende a uma lógica binária, mas corresponde a uma organização de forças em um método analógico que utiliza "verdadeiras técnicas de composição, no sentido artístico do termo" (GOLDMAN, 20I7a, p. 25). Essa linha

\footnotetext{
${ }^{17}$ Para uma análise sobre a música no terecô e seus aspectos mais técnicos, ver Lamy (2016) e Lamy e Ahlert (2018).
} 
de análise pode igualmente lançar outra perspectiva sobre as tentativas de afastamento de algumas entidades dos toques narradas por Costa Eduardo (1948) e Ferretti (I993), a qual conta, na perspectiva do tambor de mina, que

Embora D. Denis, da Casa das Minas-jeje, tenha afirmado que, no tempo de Mãe Andresa (1914-I954), Légua-Boji gozava de alto prestígio naquela casa (onde é conhecido como cambinda e como uma das entidades espirituais mais velhas de Codó), Mãe Elzita, do terreiro Fé em Deus, lembra que tanto ele, como Rei Surrupira (pai de Surrupirinha, chefe de sua casa na linha de caboclo), foram vítimas de hostilidades em terreiros de São Luís e eram despachados nos "toques" de Mina logo depois que chegavam no barracão.

$[\ldots]$

É também possível que aquelas entidades fossem despachadas apenas por receio de que, sendo guerreiras, viessem provocar brigas no terreiro, o que não só estragaria a festa como também acarretaria problemas com a polícia. (FERRETTI, I993, p. 205).

Costa Eduardo (1948) assevera que, em Santo Antônio dos Pretos,

Apesar de não haver oferendas a Légua como há no Daomé ou nas casas de culto baianas onde são oferecidos sacrifícios a ele antes do início de qualquer cerimônia, uma música é cantada em todas as danças em Santo Antônio para mandá-lo embora, apesar de que se diz que ele não se importa e continua dançando.

Arretira o Lego,

Jalí, Jalo;

Adeus, Seu Legua já vai,

Jalí, Jalo

Seu Legua é dono de terreiro [...]. (p. 6o, tradução livre)

As tentativas de evitar a chegada da entidade, despachá-la ou, mais ainda, atuar no sentindo de acalmar um pouco da sua força sem necessariamente pretender afastá-la de todo, podem ser justamente um exercício de modulação de forças. As doutrinas cantadas e as viradas para a mina, portanto, são ferramentas utilizadas em tal operação de modulação de forças. Operação análoga foi explicada por Pai Mano a Barbosa Neto(2OI2). No trecho, o autor comenta alguns procedimentos levados a cabo quando da chegada de um orixá: "Perguntei a 
Pai Mano a razão desse gesto, e ele me explicou que o seu propósito é 'tirar do santo um pouco da sua força, pois, como ele chega cru, o corpo não aguentaria a aproximação" (BARBOSA NETO, 2OI2, p. 44). Na obra de Costa Eduardo (1948), outro procedimento encontrado em terreiros de São Luís chama atenção: o batismo de encantados. Segundo o autor, "alguns espíritos caboclos dizem desgostar do batismo porque perdem parte de suas forças e não podem dançar tão irrefreadamente como antes" (p. 75).

A explicação dos brincantes que afirma que "nada mudou" e que a virada se dá apenas para "descansar os médiuns" revela que não há efetivamente uma mudança de lado, nação ou vertente espiritual, como é comum em outros contextos relativos a religiões de matriz africana, como o candomblé e mesmo o batuque; em lugar disso, a virada não se dá para uma linha ou vertente "externa", mas provoca uma variação entre elementos já presentes. Para utilizar o raciocínio de Barbosa Neto (2012) sobre o batuque no Rio Grande do Sul, a proximidade entre a mina e a mata se dá por dentro da separação existente entre elas. No exercício dessa composição, as coisas já não são mais exatamente o que eram, o que também não implica terem virado totalmente outra coisa; a convivência engendra algum tipo de mutação, mas muito mais referida talvez a reversões de figura e fundo em que os domínios se afetam mutuamente, eclipsando um ao outro sem que haja síntese, para usar a noção de Wagner (2015). Tal dinâmica não é binária, de sorte que, se nem a mata nem a mina estão totalmente ausentes - caindo por terra uma dicotomia entre "de fora" e "de dentro" -, essa presença é modulada em sua intensidade em um exercício de composição que podemos entender como artesanal, de modo que os elementos em jogo se ajuntam sem se misturarem (SANTOS, 2019).

Há, assim, uma elaborada relação entre o tambor da mata e o tambor de mina, que também abraça a linha de Codó, como afirma Ferretti (1993). A autora relata dinâmica análoga no toque de mina da Casa Fanti-Ashanti, em São Luís, com uma virada para a mata:

Começa com um canto para Exu [...] e para outras entidades espirituais africanas, numa ordem preestabelecida. Num segundo momento, o 'tambor' 'vira prá mata' - passa-se a homenagear as principais entidades caboclas da casa. Num terceiro momento, volta-se a homenagear as entidades espirituais africanas e encerra-se o 'toque' com um canto para Légba. Na Casa Fanti-Ashanti, antes do tambor 'virar prá mata', canta-se para o vodum Averequete e quando se volta a homenagear as entidades africanas canta-se primeiro para Badé Queviossô (outro vodum da Casa das Minas, da mesma família de Averequete, conhecido no Maranhão como nagô).(p. 297298, grifo nosso). 
As dinâmicas resultantes da presença do terecô na mina e da mina no terecô, é preciso explicitar, não se confundem. Talvez haja, nesse sentido, um processo de incorporação de elementos da mina pelo terecô e do terecô pela mina sem que isso implique necessariamente um amálgama que "descaracterize" um ou outro, no sentido da preocupação expressa em parte da literatura no que tange aos encontros entre diferentes vertentes religiosas e à probabilidade de uma eventual "perda de tradições". O terecô, de certa forma, aparece em outros contextos, tanto em São Luís como em outras casas religiosas de matriz africana no Piauí, no Pará e além. ${ }^{18}$ Não adentro aqui essa seara justamente porque, nesse caso, são modos singulares, constituintes dessas outras práticas de se relacionar e eventualmente incorporar atravessamentos, fluxos, práticas rituais ou entidades. Mesmo a virada para a mata de que trata Ferretti(1993), a partir do tambor de mina, guarda suas singularidades no que se refere às viradas presentes no terecô. Assim, não se trata de buscar alguma equivalência generalizada nas diferenças, como se a presença da mata na mina e da mina na mata fosse simplesmente produzir resultados espelhados.

Do ponto de vista do terecô de Codó, o modo como aciona sua relação com a mina se revela em parte nas recorrentes viradas entre mata e mina. Mais uma vez, isso não implica que as conexões com quaisquer outras vertentes produzam o mesmo tipo de relação a partir de algo que poderia ser entendido como a incorporação de um mesmo tipo de elemento. Creio que esse caminho de pensamento resultaria justamente em uma visão novamente estática sobre as práticas afro-diaspóricas. Assim, as viradas para a mina emergem como elementos que constituem o terecô de Codó hoje, o que não significa que tenha sido sempre assim ou que as coisas tenham se passado conforme um modelo estático atravessando os tempos. O modo pelo qual atualiza suas forças é dinâmico, se dá em movimento, no curso dos acontecimentos. O terecô pode, então, ser pensado tal qual "um território composto a partir dos ritmos que ele próprio agencia" (MARQUES, 20I6, p. 60). O agenciamento de "ritmos", nesse caso, parece ganhar uma particular literalidade - mas não se restringe a isso, e creio que segue potente uma noção de "ritmo" então mais amplamente considerada. Dessa maneira,

poderíamos pensar o fazer no candomblé enquanto a constituição de um território existencial (que "engata" com uma multiplicidade de territórios outros). [...] No candomblé, o território (o terreiro) é um território vivo, carregado de estórias dos fazeres que já se fizeram e que se farão naquela terra: onde o axé foi plantado, o sangue derramado, a ligação divina atualizada. A terra, e tudo que está sobre ela, ultrapassa o humano e suas

\footnotetext{
${ }^{18}$ Por exemplo, a "linha da mata de Codó" em terreiros de mina de São Luís (MA) (FERRETTI, 1993) e o "povo de Codó" em um terreiro de mina nagô em Ananindeua (PA) (VERAS, 2015).
} 
pretensões. Entretanto, isso não exclui o fato de que, para existir, ela tem que ser feita por ele - uma feitura que, como vimos, atua por composição de multiplicidades. Assim, mais que um espaço carregado de histórias, a casa é um espaço que propicia fazeres, cuidados específicos e diálogos íntimos entre pessoas e deuses. (MARQUES, 2016, p. 60-6I).

A questão, portanto, é pensar em termos de um modo de habitar territórios existenciais, algo que enreda pertencimento e devir e compõe maneiras singulares de engatar com "uma multiplicidade de territórios outros". Nesse sentido, como elaborou a mãe de santo Maria dos Santos acerca da presença ou não das viradas para a mina no tempo de Maria Piauí, 19 "sempre teve a mina, mas aqui é mata": no âmbito do terecô, a presença da mina se dá nos termos da mata.

Abdias Nascimento(20I6) reconheceu como legítimo encontro, ou "efetivo sincretismo", as interações que pressupõem "condições que assegurem a espontaneidade e liberdade daqueles que fazem intercâmbio" (p. 134). Cita Wade Abimbola para assinalar essa fundamental distinção: "[o]s tradicionalistas africanos respeitam a fé dos outros como igualmente autêntica, e como uma experiência na qual eles mesmos podem tomar parte" (ABIMBOLA apud NASCIMENTO, 20I6, p. I36, grifo nosso). Nesse sentido, as possibilidades de encontro são múltiplas, assim como o que se faz a partir dele - desde que observadas as condições que estabelecem certo plano de relação que viabiliza o encontro em toda a sua potência de indeterminação.

Em um movimento análogo ao que Nascimento (2016) fez com a noção de sincretismo, emerge a questão: será encontro um termo apto a dar conta de interações de ordens tão fundamentalmente distintas? Não se trata, com isso, de negar a validade das argumentações que fizeram uso desse termo, mas marcando a distinção. Talal Asad (I973), em sua introdução

\footnotetext{
${ }^{19}$ Maria Piauí é importante referência no terecô de Codó. A mãe de santo Iracema, sua herdeira, contou a Ahlert (2013) que Maria Piauí chegou a Codó a convite de Eusébio Jansen, tido como pai de santo da primeira tenda de terecô da cidade (no perímetro urbano). Segundo o Instituto Histórico e Geográfico de Codó, a tenda da mãe de santo foi fundada em 1938; Costa Eduardo (1948), que fez campo na região nos anos 1940, não encontrou casas abertas na cidade (mas presenciou uma "brincadeira" organizada na praça para que o pesquisador pudesse ver), o que não implica necessariamente a ausência, sobretudo considerando-se a intensa perseguição policial que sofriam os praticantes de terecô; M. Ferretti (2001) fala, em 1936 e 1948, com base em informações divergentes encontradas. A autora afirma também que "[s]egundo Pai Crispim, sucessor daquela mãe-de-santo, alguns anos após a abertura de seu terreiro em Codó, Maria Piauí foi 'confirmada' na Mina, em São Luís, por Noêmia Fragoso, fundadora do Terreiro do Cutim (cambinda), e passou a tocar Mina e Mata em sua casa, em dias diferentes. A integração da Mina com a Mata (Terecô), num mesmo ritual, parece ter ocorrido primeiro no terreiro de Bita do Barão que, como o de Maria Piauí, foi aberto dentro dos 'preceitos' da Mata" (1993, p. 140). Mãe Maria dos Santos me contou que alcançou baiar nesses terreiros (de Eusébio Jansen e Maria Piauí) e "antes era tudo terecô" até que Maria Piauí se fez na umbanda com uma mulher que veio de Teresina.
} 
ao Anthropology and the Colonial Encounter, faz uso justamente da noção de encontro adjetivando-o como colonial, assimétrico, produzido pelo que chama de uma dialética do poder mundial que transcende o momento histórico do colonialismo em sentido estrito. Diz respeito ao encontro especificamente caracterizado pela violência e pela produção de assimetrias de poder e em que medida tais interações infletiram nesse campo de estudos. Em outra abordagem, Ailton Krenak (1999) sustenta que o contato não é um evento único e pontual restrito a um marco temporal, mas transcende eventos históricos. $\mathrm{O}$ argumento estabelece, creio eu, uma distinção entre as situações que se identifica com a invasão colonial e as diversas interações entre povos e culturas. Assim, enquanto os povos indígenas forem percebidos como aqueles a serem "descobertos" - ou dominados - e os grandes centros se apresentarem como uma ameaça, "o encontro continua sendo protelado". O encontro, me parece, só acontece efetivamente na afirmação da importância das singularidades e no reconhecimento do que "cada um desses povos traz de herança, de riqueza na sua tradição" (KRENAK, I999, p. 29). Menos do que a terminologia em si, me pergunto se as diferenças entre tais interações são de ordem tal que requerem sua explicitação: os domínios da aniquilação e da potência de criação não se confundem. A questão, portanto, é pensar se há algo em uma dinâmica intrinsecamente violenta que possa ser tratado em algum plano de igualdade com interações que recusam o pressuposto de que a combinação só pode existir se não houver diferenças, ou se elas forem subsumidas ao poder e à dominação.

Em outros termos, trata-se de considerar que bons e maus encontros pressupõem que haja efetivamente um encontro - pensado, portanto, entre fluxos minoritários como tais, que em nada se confundem com pretensões de subjugação, mas se abrem à possibilidade de efetiva combinação criativa. Retornando a Abimbola e Nascimento (2016), são necessárias uma série de ativações que viabilizem "a espontaneidade e a liberdade" e o reconhecimento da "fé dos outros como igualmente autêntica", como um pressuposto para aqueles que se lançam aos encontros nessa chave. Tomar parte na fé do outro é, em tal perspectiva, perfeitamente concebível, e não implica necessariamente desrespeito, violência ou perda irreversível de si. Antes, nos fala das maneiras pelas quais um encontro respeitoso abre caminho para a potencialização de forças ou, utilizando a imagem de Anjos (2008) para a possessão, é "o 'outro' introduzido no 'mesmo' fazendo explodir a mesmidade como possibilidade de pensar e ser" (p. 85-86). Assim, ora as diferenças se aproximam, ora se distanciam, em uma tessitura que, ciente dos riscos, não se furta a compor os variados elementos presentes. Como afirmou Marques (2016), é como se tudo "atravessasse distintos territórios existenciais, que se constituem através da modulação e da composição de forças, em um engajamento contínuo de pessoas, deuses e coisas" (p. I37). 
A constituição desses territórios se efetua por processos de "diferenciação e individuação", de modo que "a unidade dessa força [o axé] garante que tudo participa em tudo, mas as suas modulações fazem com que haja graus de participação", como afirma Goldman (2009, p. I23, grifo nosso). Nos movimentos de circulação desenham-se trajetórias dinâmicas que inscrevem marcas nos percursos - no instante de um novo aprendizado, de uma experiência, de alguma singular articulação entre diferenças. Seguindo o raciocínio de Santos (2019), os movimentos de encontros confluentes ou transfluentes só podem se dar em termos muito diferentes de um amálgama indistinto, homogeneizador e aniquilador das diferenças, justamente porque as singularidades do próprio percurso e dos modos pelos quais os encontros se efetivam seguem em relevo, não são obliteradas. As diferenças constituintes das singularidades em contato são mantidas - incluindo aí um movimento dinâmico de ativação de múltiplos mecanismos que cuidam para que o encontro seja efetivamente o que se propõe a ser, um encontro; aquilo que só pode mesmo se dar na diferença e em suas modulações. Entre riscos e vulnerabilidades, preparações e cuidados, experiências exitosas ou malsucedidas, um encontro não se apresenta de saída diante do horizonte da morte (FERREIRA DA SILVA, 2006), e sim aquilo que emerge das experimentações e modulações criativamente vivas. O próprio percurso importa e, por essa perspectiva, circular é diferir e singularizar.

Assim, as visitas e as viradas do terecô podem ser vistas como técnicas que possibilitam não apenas a circulação do axé, da energia, das forças, mas as possíveis capturas que ocorrem nesse processo. As viradas podem ser pensadas como visitas da mina à mata - e visitas da mata a outros lugares são também possíveis, embora provavelmente em termos outros. Em um universo em que "o facto de nada faltar não significa que nada haja a fazer" (GOLDMAN, 2009, p. 134), deixar um pouco de si e levar um pouco do outro não significa necessariamente "perder" algo. Nesses termos, a presença da mina não implica haver "menos" terecô nem "menos" mina. Encontrar, então, é capturar algo do outro e deixar que se capture algo de si, em uma dinâmica em que o horizonte - concebendo os riscos e os cuidados necessários - é a potencialização das forças. Pensar o terecô na chave da constituição de territórios existenciais - ou seja, a partir dos ritmos que ele próprio agencia - é pensar que esses movimentos de virada e visita o constituem de tal modo que "sempre teve mina, mas aqui é mata", nas palavras de mãe Maria dos Santos. Assim, as visitas da mina ao terecô atualizam e compõem o que constitui o território existencial da mata - e a mata também pode visitar, habitar e atualizar, de algum modo, o tambor de mina, compondo e sendo composta no engajamento com outros territórios existenciais.

É assim que o que Anjos (2006, 2008) chama de filosofia das diferenças das religiosidades afro-brasileiras pode fazer reativar uma interessante intuição de Bastide(I97I) que terminou obliterada por uma percepção de "confusão sincrética" enfraquecedora e 
lastreada na miséria sobre as práticas mencionadas no início deste artigo. Sobre a religiosidade na "zona rural" maranhense, Bastide (I97I) afirmou ter "a impressão de se estar numa encruzilhada de religiões, ou antes, num beco sem saída em que se encontram as mais diversas místicas" (p. 26I). No entanto pensar "a encruzilhada como ponto de encontro de diferentes caminhos que não se fundem numa unidade, mas seguem como pluralidades" (ANJOS, 2006, p. 2I) a partir do modelo rizomático do encontro das diferenças faz inverter a proposição. Por esse viés, não há que se falar em "estranhas uniões" ou em algo que degrade movimentos tão complexos. Isto é, longe de um "beco sem saída", uma mistura confusa e enfraquecida supostamente destinada à obliteração, trata-se, ao contrário, exatamente de uma "encruzilhada de religiões" que afirma a multiplicidade e permite o movimento, a circulação e a diferença.

\section{Agradecimentos}

Este artigo consistiu basicamente em um remanejamento de parte de minha dissertação de mestrado, defendida em fevereiro de 2018, no Programa de Pós-Graduação em Antropologia Social do Museu Nacional (UFRJ). A pesquisa segue atualmente no curso do doutorado pela mesma instituição, e é fruto, até o momento, de cerca de nove meses de trabalho de campo, entre 2017 e 2019. Conta com o apoio provido pela bolsa de mestrado da Coordenação de Aperfeiçoamento de Pessoal de Nível Superior (CAPES), pela bolsa de doutorado da Fundação de Amparo à Pesquisa do Estado do Rio de Janeiro (FAPERJ), ao doutorado-sanduíche proporcionado pela Fundação Fulbright e aos recursos do Conselho Nacional de Desenvolvimento Científico e Tecnológico (CNPq) referentes ao projeto coletivo "Relações Afroindígenas: Teorias Etnográficas da Mistura", coordenado por Marcio Goldman, ao qual esse trabalho está relacionado.

Agradeço pelos generosos comentários de Marcio Goldman, Lucas Marques, Olavo Souza, Noshua Amoras, Gabriel Banaggia e Clara Flaksman às primeiras versões deste artigo. Também dedico agradecimento especial aos ensinamentos de mães e pais de santo: Teresinha (Tenda Espírita de Umbanda Nossa Senhora da Conceição), Domingueiro (Tenda Espírita de Umbanda Santa Bárbara), Maria dos Santos (Tenda Espírita de Umbanda Santa Bárbara), Iracema (Tenda Espírita de Umbanda Santo Antônio), Maria Júlia (Tenda Espírita de Umbanda Santa Luzia), Café (Tenda Espírita de Umbanda São Cipriano), Pedro d'Oxum, tamboreiro Piauí, bem como a seus filhos de santo, filhos, afilhados, guias, encantados e integrantes em geral de suas casas. 


\section{Referências}

AHLERT, M. Carregado em saia de encantado: transformação e pessoa no terecô de Codó (Maranhão, Brasil). Etnográfica, v. 20, n. 2, p. 275-294, 2016.

AHLERT, M. Cidade relicário: uma etnografia sobre terecô, "precisão" e encantaria em Codó (MA). 20I3. Tese (Doutorado em Antropologia Social) - Programa de Pós-Graduação em Antropologia Social, Universidade de Brasília, Brasília, 2013.

AHLERT, M.; LIMA, C. A família de Légua está toda na eira: tramas entre pessoas e encantados. Etnográfica, v. 23, n. 2, p. 447-467, 2019.

AMORAS, N. "A jurema manda": notas iniciais sobre o trabalho de campo com uma religião em Recife, PE. Palestra ministrada no evento Sextas na Quinta. Rio de Janeiro: Núcleo de Antropologia Simétrica, Museu Nacional, Universidade Federal do Rio de Janeiro, 2020. Trabalho não publicado.

ANJOS, J. C. dos. A filosofia política da religiosidade afro-brasileira como patrimônio cultural africano. Debates do NER, Porto Alegre, n. I3, p. 77-96, 2008.

ANJOS, J. C. dos. No território da linha cruzada: a cosmopolítica afro-brasileira. Porto Alegre: UFRGS, 2006.

ASAD, T.(Ed.). Anthropology and the Colonial Encounter: 9-19. New York: Humanities, 1973. Introduction.

BANAGGIA, G. Inovações e controvérsias na antropologia das religiões afro-brasileiras. 2008. Dissertação (Mestrado em Antropologia Social) - Programa de Pós-Graduação em Antropologia Social, Museu Nacional, Universidade Federal do Rio de Janeiro, Rio de Janeiro, 2008.

BANAGGIA, G. Religiões de matriz africana em perspectiva transformacional. Revista de Antropologia da UFSCAR, v. 6, n. 2, p. 57-70, jul./dez. 2014.

BARBOSA NETO, E. R. A máquina do mundo: variações sobre o politeísmo em coletivos afro-brasileiros. 2012. Tese (Doutorado em Antropologia Social) - Programa de Pós-Graduação em Antropologia Social, Museu Nacional, Universidade Federal do Rio de Janeiro, Rio de Janeiro, 2012.

BASTIDE, R. As religiões africanas no Brasil: contribuição a uma sociologia das interpretações de civilizações. São Paulo: Pioneira Editora, I97I.

COSTA EDUARDO, O. The negro in Northern Brazil: a study of acculturation. New York: J.J. Austin Publisher, 1948.

CRUZ, B. P. da S. Confluências e transfluências no terecô, religião de matriz africana de Codó, Maranhão. 20I8. Dissertação(Mestrado em Antropologia Social) - Programa de Pós-Graduação em 
Antropologia Social, Museu Nacional, Universidade Federal do Rio de Janeiro, Rio de Janeiro, 2018.

FERREIRA DA SILVA, D. À brasileira: racialidade e a escrita de um desejo destrutivo. Revista de Estudos Feministas, Florianópolis, v. I4, n. I, p. 6I-83, jan./abr. 2006.

FERRETTI, M. Desceu na Guma: o caboclo no tambor de mina no processo de mudança de um terreiro de São Luís - a Casa Fanti-Ashanti. São Luís: SIOGE, 1993.

FERRETTI, M. Encantaria de Barba Soeira: Codó, capital da magia negra? São Paulo: Siciliano, $200 I$.

FERRETTI, S. Querebentam de Zomadonu: etnografia da Casa das Minas. São Luís: EDUFMA, 1985.

FERRETTI, S. Repensando o sincretismo. São Paulo: Edusp, I995.

GOLDMAN, M. Contradiscursos afroindígenas sobre mistura, sincretismo e mestiçagem: estudos etnográficos. In: PAZZARELLI, F.; SAUMA, J.; HIROSE, M. Revista de Antropologia da UFSCAR, Dossiê (Contra) Mestiçagens Ameríndias e Afro-Americanas, v. 9, n. 2, p. II-28, jul./dez. 20I7a.

GOLDMAN, M. "Nada é igual": modulação, devir e respeito nos saberes afroindígenas, 2017. Conferência apresentada no seminário A Relação Afroindígena na Bahia e Alhures: Cosmopolíticas em Contato. Salvador: Universidade Federal da Bahia, 20I7b.

GOLDMAN, M. Histórias, devires e fetiches das religiões afro-brasileiras: ensaio de simetrização antropológica. Análise Social, v. XLIV, n. 190, p. IO5-I37, 2009.

GOLDMAN, M. O dom e a iniciação revisitados: o dado e o feito em religiões de matriz africana no brasil. MANA, Rio de Janeiro, v. I8, n. 2, p. 269-288, ago. 2012.

GOLDMAN, M. Quinhentos anos de contato: por uma teoria etnográfica da (contra)mestiçagem. MANA, v. 2I, n. 3, p. 64I-659, 2015.

GOLTARA, D. B. Dá um S na corrente: a rede esotérico-umbandista às margens do rio Itapemirim. 20I4. Tese (Doutorado em Antropologia Social) - Programa de Pós-Graduação em Antropologia Social, Universidade de Brasília, Brasília, 2014.

GOLTARA, D. B. Ligando a corrente: ensaio sobre a relação entre espiritualidade e socialidade nas irmandades religiosas de matriz africana no Vale do Itapemirim. Religião e Sociedade, Rio de Janeiro, v. 36, n. I, p. 34-55, 2016.

JONES, L. Blues People: Negro Music in White America. New York: Harper Perennial, 2002. KRENAK, A. O eterno retorno do encontro. In: NOVAES, A. (Org.). A outra margem do Ocidente. São Paulo: Minc/Funarte; Companhia das Letras, 1999. 
LAMY, M. Força e criatividade a partir da música no terecô em Codó (Maranhão). 20I6. Monografia (Graduação em Ciências Sociais) - Universidade Federal do Maranhão, São Luís, 2016. LAMY, M; AHLERT, M. Música, agência e força no terecô em Codó (Maranhão). 20I8. PROA, Revista de Antropologia e Arte, Campinas, v. 2, n. 8, p. I82-203, jul./dez. 2018.

LIMA, C. Pagamento de tambor: conexões e visitas no terecô em Codó (Maranhão). 2019. Dissertação (Mestrado em Ciências Sociais) - Universidade Federal do Maranhão, São Luís, 2019.

LIMA, C. Relações cruzadas: uma etnografia sobre vínculos entre pessoas e encantados no terecô de Codó - Maranhão. 20I7. Monografia (Graduação em Ciências Sociais) - Universidade Federal do Maranhão, São Luís, 2017.

MARQUES, L. Caminhos e feituras: seguindo ferramentas de santo em um candomblé da Bahia. 2016. Dissertação (Mestrado em Antropologia Social) - Programa de Pós-Graduação em Antropologia Social, Museu Nacional, Universidade Federal do Rio de Janeiro, Rio de Janeiro, 2016.

MOTTA, R. Bandeira de Alairá: a festa de Xangô-São João e problemas do sincretismo. In: Moura, C. (Org.). Bandeira de Alairá: outros escritos sobre a religião dos orixás. São Paulo: Nobel, 1982.

NASCIMENTO, A. O genocídio do negro brasileiro: processo de um racismo mascarado. São Paulo: Perspectivas, 2016.

PINTO FILHO, O. S. O coincidir dos santos. Imagens e reversões no candomblé nagô do Recife. In: PAZZARELLI, F.; SAUMA, J.; HIROSE, M. Revista de Antropologia da UFSCAR, Dossiê (Contra) Mestiçagens Ameríndias e Afro-Americanas, v. 9, n. 2, p. I35-I52, jul./dez. 2017 .

PRANDI, R.; SOUZA, P. R. Encantaria de Mina em São Paulo. In: PRANDI, R. (Org.). Encantaria brasileira - o livro dos mestres, caboclos e encantados. Rio de Janeiro: Pallas, 20II. p. 216280 .

SANTOS, A. B. Colonização, quilombos: modos e significações. Brasília: Editora Ayô, 2019. SERRA, O. Águas do rei. Petrópolis: Vozes, 1995.

VERAS, H. de S. O sacerdote e o aprendiz: etnografia, experiência e ritual em um terreiro de mina nagô na Amazônia. 2015. Dissertação (Mestrado em Antropologia Social) - Programa de PósGraduação em Antropologia, Instituto de Filosofia e Ciências Humanas, Universidade Federal do Pará, Belém, 2015.

WAGNER, R. A invenção da cultura. São Paulo: Cosac Naify, 2015. 